\title{
AVALIAÇÃO OBJETIVA DE SUPERFÍCIE ASFÁLTICA PELA DETERMINAÇÃO DO IGG NA RUA PADRE EGÍDIO CARMELINK, BELFORD-ROXO, RJ
}

\author{
Elena Reis Rodrigues ${ }^{1}$ \\ Leandro da Rocha $\mathrm{Vaz}^{2}$
}

Resumo: Os investimentos em infraestrutura viária são grandes alavancadores do desenvolvimento econômico de uma região. Os projetos de pavimento flexível são geralmente feitos para uma vida útil de 5 anos, assim após esse prazo são necessárias intervenções para restauração. Em Belford-Roxo, RJ, a pavimentação da maior parte da cidade não atende as condições básicas que a população necessita. Buscou-se particularizar tal problema, segundo a ótica e os processos de avaliação contidos no Manual de Restauração de Pavimentos Asfálticos do Departamento Nacional de Infraestrutura de Transportes utilizando o método da avaliação objetiva de superfície pela determinação do Índice de Gravidade Global. A aplicação adaptada para vias locais mostrou-se efetiva, pois relata de forma simplificada a condição funcional do pavimento. Uma vez que pouco se usam essas técnicas, essa aplicação se faz pertinente para um adequado projeto de restauração evitando aplicação de recursos desnecessários.

Palavras-chave: Pavimentos urbanos, patologias em pavimentos, levantamento visual.

\footnotetext{
1 UNIGRANRIO/ECT, Brasil. E-mail: elenareisrodrigues@gmail.com.

2 UNIGRANRIO/ECT, Brasil. E-mail: leandro.vaz@bol.com.br.
} 